\title{
Effects of brand placement and player involvement on brand awareness: an empirical study on online game players
}

\author{
Bonit Bogonondo ${ }^{1}$ and Yessy Artanti ${ }^{1}$ \\ ${ }^{1}$ Department of Management, Faculty of Economics, Universitas Negeri Surabaya
}

\begin{tabular}{ll}
\hline Abstract & This paper examines the effects of brand placement and player involvement on brand \\
awareness. The data in this study were collected from questionnaires distributed to \\
150 game players of online game with snowball sampling. Data analysis used multiple \\
regression analysis. However, our prediction that there were effect of brand \\
placement and player involvement on brand awareness was not supported. We \\
presents the discussions in this paper.
\end{tabular}

Keywords

brand placement; player involvement; brand awareness

\section{INTRODUCTION}

The entertainment industry continues to develop in line with technological developments. Consumer interest shifted toward entertainment that originated from traditional entertainment turning to technologybased entertainment and information. Factors practicality and convenience provided by the technology continues in changes of interest and perception of the reference item that has a destination for entertainment. Technology that moves on the wider development entertaintment industry with the massive growth of various online-based media. The development of the Internet creates a significant change and contribute to the change in communication patterns of society. Use of the Internet allows a person to make contact with other people who are in the other hemisphere. Internet in its development is now widely used by school age to adulthood. In everyday use the Internet can be used include searching for the latest news, socialize through chat feature to share information through forums, to play games online. Children and adults who play these games marketing potential targets for marketers.

Potential development of online-based games requires marketers to prepare the next strategy. In contrast to other electronic media, advertising in games media is able to bring the experience to consumers about the ads appearing without coercion and without consumers feel directly. A game player is required to focus $100 \%$ focused on the game they're playing (Marketing, February 2013: 130). With a high level of focus that is able to connect the brand with the player and easily understood information processing. It allows the marketing department to project its marketing strategy using a variety of electronic media, especially online games.

One of the main factor to make success a product in the market is the way company creating and maintaining a brand. Brand is an identity which differentiates a product from another product in the market. A brand factor also becomes a determine for a consumer to choose a product. The consumer will choose and buy a product based on quality and value of the product. Consumer memories about the brand are determined with recognizing the new product and past memories with that product. The Company tries to strengthen its brand equity to give some impacts to consumer memory by showing brand to the easiest media to find, fast in remembering product information, and awareness by the placement of the brand (brand awareness). Brand awareness is a part of brand equity and the level of an unknown brand is known now (Aaker, 1991). In the highest level of brand awareness, the company demanded to be able to capture consumer interest using marketing media from the product who has an emotional attachment with the consumer. Brand placement is an integrating practice of brand to an entertainment media, especially television and movie (Thomas and Kohli, 2011). 
Company use strategy brand placement method in product to the part of an event or movie which has entertaining goals. Panda (2004) said that brand placement is inserted product in television and online media with a purpose to get intention and consumer memories about brand and make it easier to know product. Research of Gupta and Lord (1998) propose that brand placement is the extent of brand display has characteristics that design to be able to focus and attention point of audiences. D'Astous dan Cartier (2000) said that brand placement is a new alternative media that could be a convenient communication tool. Brand placement could find in the television series or show, theater drama, song, video game, and novel (Kretchmer, 2004; Moser et al., 2004). Brand placement could use in any media like movie, television program, music video, video games, and other media (Karrh, 1998). Almost in every movie and television program show brand placement for more effective reach consumer attention. Brand placement consists of two dimensions such as prominence brand placement and subtle brand placement with the untangible placement (Gupta \& Lord, 1998).

To examine this study we selected Arena of Valor (AOV) games as our object research. We choose Arena of Valor based on the fact that many some company brands (OPPO, DC) put their brand in this game. The purpose of this study was to determine the influence of brand placement and player involvement on brand awareness.

\section{HYPOTHESES DEVELOPMENT}

\section{Brand placement and brand awareness}

According to Panda (2004), brand placement is a product that is embedded in television media, and online-based media with the aim of getting consumer attention and memory about the brand and making it easier for consumers to get to know the product. Research conducted by Gupta and Lord (1998) suggests that brand placement is the extent to which the brand's appearance has characteristics designed to make it the focus and attention of the audience. d'Astous and Cartier (2000) argue that brand placement is a new media alternative that can be used as a conventional communication tool. There are several brand placements that can be found in television series or shows, theater dramas, songs, videogames, and novels (Kretchmer, 2004; Moser et al., 2004. In-game placement or advertising in games (advergame) is a new technique used by marketers to promote your brand and ensuring that the message in the ad (Gould and Gupta, 2006). Moore (2006) argues that in-game advertising or advergame is a form of advertising media in the context of entertainment that displays advertising messages, logos and characters into promotional purposes in the format of games. Nelson (2002) suggests that memorybased brand placement in games overall computer displays will be remembered better than brand placement at the bit in the games. Winkler and Buckner (2006) classified the types of brand placement to three category: associative placement; illustrative placement; demonstrative placement. This study only use the illustrative and demonstrative placement because the associative placement is considered to have been able to influence the brand awareness.

\section{H1: Illustrative brand placement positively influences on brand awareness}

H2: Demonstrative brand placement positively influences on brand awareness

\section{Player involvement and brand awareness}

Engagement with games is a situation where players are motivated to exert cognitive effort while playing games (Lee \& Faber, 2007, p. 77). There are several results of research on building engagement. Some researchers suggest involvement as a process of receiving information (Greenwald and Leavitt, 1984). Most researchers seem to agree that involvement is based on motivation (Laczniak, Muehling, and Grossbart, 1989; Pham, 1992). The results of other studies state that consumers who have greater involvement with certain programs will allocate greater cognitive effort to the program (Krugman 1983; Lloyd and Clancy 1991). Involvement with this increased program, in turn, will also bring accompanying advertisements, thus giving businesses more processing of advertisements. Pham (1992) found a relationship between involvement (low, middle and high) by watching football matches on television and attention to sponsor brands on the sidelines around the game. Folkvord et al. (2015) also proved that advergames provide memory to consumer behaviour, and other things about brands. Higher levels of involvement lead to positive and better attitudes towards advertising and brands are being advertised (Lee, Hu \& Toh, 2000). 
Another study also said that a game with a low perceptual load produces much higher brand memory than a game that has a high perceptual load (Kureshi and Sood, 2009). Games allow active use and more intense attention and ad messages can be easily captured by players of a particular game. Consumers will be actively involved in playing games, different than when watching programs on television or on film consumers only engage passively (Nicovich, 2005).

H3: Player involvement positively influences on brand awareness

\section{METHODS}

\section{Data collection}

The population in this study are respondents were players from the Arena of Valor game with an age range of 16-35 years with male and female gender, had or were playing games either individually or in a community group on the @garenaaovid official Instagram account. Data are collected by distributing 114 questionnaires to respondendts using nonprobability sampling (purposive and snowball sampling). The main advantage of snowball sampling is that this sampling increases the chances of finding the desired characteristics in the study population.

The researcher distributed questionnaires that had been compiled in Google Form and the researcher would provide an online questionnaire link to respondents who had characteristics in accordance with the research. The way researchers take samples is that researchers contact potential respondents through direct message to followers of the official @aov_surabaya account on the Instagram application and ask the respondent according to the characteristics sought in this study. After the respondents filled out the online questionnaire, researchers will ask for recommendations to the respondents who are prospective respondents that match the characteristics sought by researchers.

Result study in table 1 reports the majority of respondents were male $(93,9 \%)$. The respondents sample were mostly aged 20-23 years $(37,7 \%)$ and most of the respondent spend their time with the games is 3-5 hours a day $(54,4 \%)$ with the most types of games played MOBA $(71,9 \%)$. Open question test results obtained by brands with the majority of respondents were Fruit tea $(53,5 \%)$.
Table 1.

Demographic profile of respondent

\begin{tabular}{cccc}
\hline Profile & Kategory & Freq & $\%$ \\
\hline \multirow{2}{*}{ Gender } & Male & 107 & $93,9 \%$ \\
& Female & 7 & $6,1 \%$ \\
\hline \multirow{5}{*}{ Age } & $13-15$ & 7 & $6,1 \%$ \\
& $16-19$ & 29 & $25,4 \%$ \\
& $20-23$ & 43 & $37,7 \%$ \\
& $24-27$ & 30 & $26,3 \%$ \\
& $28-31$ & 5 & $4,4 \%$ \\
& $32-35$ & 0 & $0 \%$ \\
\hline \multirow{3}{*}{ Duration } & $1-2$ hour & 41 & $36 \%$ \\
\cline { 2 - 4 } & $3-5$ hour & 62 & $54,4 \%$ \\
\cline { 2 - 4 } & $>5$ hour & 11 & $9,6 \%$ \\
\hline \multirow{5}{*}{ type } & Action & 7 & $6,1 \%$ \\
& Adventure & 2 & $1,8 \%$ \\
& MMORPG & 9 & $7,9 \%$ \\
\cline { 2 - 4 } & Puzzle & 0 & $0 \%$ \\
\cline { 2 - 4 } & Racing & 2 & $1,8 \%$ \\
\cline { 2 - 4 } & FPS & 9 & $7,9 \%$ \\
\cline { 2 - 4 } & Sport & 3 & $2,6 \%$ \\
\cline { 2 - 4 } Brand & MOBA & 82 & $71,9 \%$ \\
\cline { 2 - 4 } & Fruittea & 61 & $53,5 \%$ \\
\cline { 2 - 4 } & OPPO & 45 & $39,5 \%$ \\
\cline { 2 - 4 } & DC & 8 & $7 \%$ \\
\hline \multirow{5}{*}{ typ }
\end{tabular}

\section{Measurement}

Brand placement was measured using 3 dummy variables developed by Vashisht and Pillai (2015). Player involvement was measured using 12 items, 8 items developed by Calleja (2011) and 4 items developed by Lessiter et al (2001). Brand awareness was measured using 7 items developed by Law and Braun (2004). All construct were measured using five points of Likert scale, ranging from 1 = strongly disagree to 5 strongly agree. The Likert scale is a measurement scale with five categories of responses that range from "strongly agree" to "strongly disagree" which requires respondents to determine the degree of agreement or their disapproval of each of a series of statements about stimulus objects (Malhotra, 2009: 298).

\section{RESULTS AND DISCUSSIONS}

\section{Validity and reliability test}

Before testing our hypotheses, we conducted validity and reliability test to our measurements. The validity test was measured using Pearson product moment while the reliability test was measured using Cronbach's alpha. The validity and reliability tests are performed to test the reliability of research variables and and the indicator validity of each variables (table 2 ). 
Tabel 2. Validity test

\begin{tabular}{cccc}
\hline Item & $\begin{array}{c}\text { Corrected } \\
\text { item total }\end{array}$ & Table $\boldsymbol{r}$ & Validity \\
\hline $\mathbf{1}$ &, 658 & .361 & Valid \\
\hline $\mathbf{2}$ &, 780 & .361 & Valid \\
\hline $\mathbf{3}$ &, 721 & .361 & Valid \\
\hline $\mathbf{4}$ &, 761 & .361 & Valid \\
\hline $\mathbf{5}$ &, 836 & .361 & Valid \\
\hline $\mathbf{6}$ &, 790 & .361 & Valid \\
\hline $\mathbf{7}$ &, 812 & .361 & Valid \\
\hline $\mathbf{8}$ &, 879 & .361 & Valid \\
\hline $\mathbf{9}$ &, 686 & .361 & Valid \\
\hline $\mathbf{1 0}$ &, 774 & .361 & Valid \\
\hline $\mathbf{1 1}$ &, 808 & .361 & Valid \\
\hline $\mathbf{1 2}$ &, 770 & .361 & Valid \\
\hline $\mathbf{1 3}$ &, 666 & .361 & Valid \\
\hline $\mathbf{1 4}$ &, 560 & .361 & Valid \\
\hline $\mathbf{1 5}$ &, 496 & .361 & Valid \\
\hline $\mathbf{1 6}$ &, 692 & .361 & Valid \\
\hline $\mathbf{1 7}$ &, 592 & .361 & Valid \\
\hline $\mathbf{1 8}$ &, 443 & .361 & Valid \\
\hline $\mathbf{1 9}$ &, 474 & .361 & Valid \\
\hline
\end{tabular}

Table 3.

Reliability test

\begin{tabular}{lcc} 
Variable & $\begin{array}{c}\text { Cronbach's } \\
\text { Alpha }\end{array}$ & Critical Value \\
\hline $\begin{array}{l}\text { Player } \\
\text { Involvement }\end{array}$ & 0,939 & 0,70 \\
\hline $\begin{array}{l}\text { Brand } \\
\text { Awareness }\end{array}$ & 0,835 & 0,70 \\
\hline
\end{tabular}

Results of validity test by using of an approach of corrected item-total correlations shows that all items used in this study are valid, as indicated by the value of $r$ of each item of which it is similar and greater than the critical $r$, 0.361 . Thus, all items of empirical indicators can be used in further data processing. Results of reliability test are based on the value of Cronbach's Alpha ( $\alpha$ ) show that two variables that are studied meet the elements of reliability with value of Alpha Cronbach ( $\alpha$ ) is greater than 0.70 (Malhotra, 2010). The reliability test are shown below in table 3 .

\section{Multiple regression analysis}

Then, analyzing using multiple linear regression to find out the influence of associative brand placement, illustrative brand placement, demonstrative brand placement and player involvement on brand awareness. The researcher processed the data using SPSS 18
Table 4.

Results of multiple regression analysis

\begin{tabular}{lccc}
\hline Model & B & t & Sig. \\
\hline $1 \quad \begin{array}{l}\text { (Constant) } \\
\text { Illustrative }\end{array}$ & 5.573 & 11.000 & .000 \\
$\quad$ Brand & .428 & 1,835 & .069 \\
$\quad \begin{array}{l}\text { Placement } \\
\quad \text { Demonstrative }\end{array}$ & & & .291 \\
$\quad \begin{array}{l}\text { Brand } \\
\quad \text { Placement }\end{array}$ & .463 & 1,062 & \\
$\quad \begin{array}{lll}\text { Player } \\
\text { Involvement }\end{array}$ & .026 & 0,204 & .839 \\
\hline a. Dependent Variable: Brand Awareness & &
\end{tabular}

software. The following is the result of multiple linear regression data processing (table 4).

\section{The effect of illustrative brand placement on brand awareness}

The result of multiple linear regression test shows Illustrative brand placement variable is a number that shows the magnitude of the error rate at the value of $t$ obtained at 1,835. Because of the signicant value the illustrative variable brand placement is $0.069>0.05$, so the illustrative brand placement variable does not affect brand awareness. $\beta$ value is 0.428 which can be concluded that illustrative brand placement has a higher brand awareness of 0.428 than associative brand placement as a dummy control variable.

\section{The effect of demonstrative brand placement on brand awareness}

The demonstrative brand placement variable is a number that shows the magnitude of the error rate at the value of $t$ obtained at 1.062 . Because of the significant value the demonstrative brand placement variable is $0.291>0.05$, then the demonstrative brand placement variable does not affect brand awareness. $\beta$ value of 0.463 which can be concluded that demonstrative brand placement has a higher brand awareness 0.463 than associative brand placement as a dummy control variable.

\section{The effect of player involvement on brand awareness}

The variable of player involvement is a number that shows the magnitude of the error rate at the value of t obtained at 0.204 . Because of the significant value player involvement variable is 0.83950 .05 , then the player involvement 
variable does not significantly influence brand awareness. the value of $\beta$ is 0.026 which means that if the involvement of players in games Arena of Valor increases, the brand awareness of the respondents will increase by 0.026 with a coefficient of positive value.

\section{Discussions}

The test results that have been carried out on the hypothesis testing table indicate that brand placement does not affect the occurrence of brand awareness. This shows that the brand placement carried out in this study is divided into three brand placement categories namely associative brand placement, illustrative brand placement and demonstrative brand placement have not been able to predict brand awareness that occurs in Games Arena of Valor. Further explanation is that brand placement conducted by companies in games cannot increase brand awareness to their players. This indicates that brand placement using two-dimensional brand placement has not been able to increase brand awareness. Brands are placed in a position where players can recognize the brand and remember it well. In this study the brands that become the category of brand placement include Fruit tea, OPPO and DC.

The results of this study support the results of Vashisht and Pillai (2015) in their research using brand placement variables using only two brand placements, namely subtle brand placement and prominent brand placement which conclude the results of their research that brand placement in the background will result in brand awareness which is lower than brand placement with placement in front which results in high brand awareness.

The results of this study are different from previous studies conducted by Kristanto et al (2016) which stated that brand placement is effective for increasing brand awareness in mass communication media and other digital media. So that companies can use brand placement in games to increase brand awareness of players or consumers. Brand placement strategies can adjust to the dimensions to be used based on the media to be used. Brand placement on media games will certainly be different from the dimensions of brand placement on film and TV shows.

If it is associated with the characteristics of respondents in this study, the brand placement of the Fruit Tea brand dominates with the highest frequency of brand awareness when compared to other brand brand placements at Games Arena of Valor. This proves that players are aware of the Fruit Tea brand and are able to capture brand messages given by marketers.

After doing the data research this results that the relationship between player involvement and brand awareness does not occur in the relationship. So that the value explains that player involvement does not affect memory about brand awareness in Games Arena of Valor. It can be concluded that the second hypothesis which states player involvement influences brand awareness is not supported.

The results of this study support previous research conducted by Chaney et al (2004) who placed the brand on game billboards stating that the level of experience of a player will not affect the ability to remember brands in games. Measurement of experience uses three ways, namely the time spent playing online games every week, the time spent playing games FPS (Shooter) type every week and how many years have played FPS type games. According to respondents why they are not able to remember the brands that are in games because of them are too busy to defeat the enemy and only focus on the game. Instead the results of this study reject the previous research conducted by Lee, Hu \& Toh (2000) which states that higher involvement will form a positive and better attitude towards the brand being advertised. The research conducted by Vashisht and Pillai (2015) also declined by stating that players with high involvement have low brand awareness compared to players who have low involvement resulting in high brand awareness.

If it is associated with the level of involvement of players in this study, respondents with high and low involvement are equally able to remember the brand placed in Games Arena of Valor. Other factors that are characteristic of engagement are based on the duration of play by the players. From the characteristics of respondents who have been examined, the majority of players play games with a duration of 3-5 hours of play in a day. Games type preferences are often played by the majority playing games with the type of MOBA game (Massive Online Battle Arena).

\section{CONCLUSION}

Based on the data analysis and the discussion above, our study found that brand placement isn't significantly affected brand awareness in online games and player involvement isn't significantly affected brand awareness as well in online games. 
Company could use the associative brand placement that proved could reach the majority of players (brands placed on background of the games). Companies could use other game categories in placing their brands because respondents objective nature to the games that are often played could spread the brand awareness to all respondents.

Some suggestions for the future researches are adding any variables such as duration of play, playfullness, understanding level of brand messages, and others. We also suggest to use new brand or fiction to devoid the bias because the brand of this study is wellknown in any media.

\section{REFERENCES}

Aaker, David A. 2013. Manajemen Pemasaran Strategi. Edisi kedelapan. Salemba Empat. Jakarta.

Ajisaksono, Y. V., \& Wiratmojo, B. (n.d.). Efektivitas Product Placement Dalam Game Online, 113.

Light, M. A., \& Light, I. H. (2008) The geographical expansion of Mexican immigration in the United States and its implication for local law enforcement. Law Enforcement Executive Forum Journal, 8(1), 73-82.

Auty, S., \& Lewis, C. (2004). Exploring children's choice: The reminder effect of product placement. Psychology and Marketing, 21(9), https://doi.org/10.1002/mar.20025 697-713

Bellman, S., Kemp, A., Haddad, H., \& Varan, D. (2014). The effectiveness of advergames compared to television commercials and interactive commercials featuring advergames. Computers in Human Behavior, 32, 276-283. https://doi.org/10.1016/j.chb.2013.12.013

Brockmyer, J. H., Fox, C. M., Curtiss, K. A., Mcbroom, E., Burkhart, K. M., \& Pidruzny, J. N. (2009). Journal of Experimental Social Psychology The development of the Game Engagement Questionnaire: A measure of engagement in video game-playing. Journal of Experimental Social Psychology, 45(4), 624-634.

https://doi.org/10.1016/j.jesp.2009.02.016

Calleja, G. (2011). In-game: From immersion to incorporation. Cambridge, MA; London: MIT Press

Cauberghe, V., \& De Pelsmacker, P. (2010). Advergames. Journal of Advertising, 39(1), 5-18. https://doi.org/10.2753/JOA00913367390101
Chaney, I. M. L. K.-H. J., Lin, K., \& Chaney, J. (2004). The Effect of Billboards within the Gaming Environment. Journal of Interactive Advertising, 5(1), 37-45. https://doi.org/10.1080/15252019.2004.1072 2092

D'Astous, A., \& Chartier, F. (2000). A study of factors affecting consumer evaluations and memory of product placements in movies. Journal of Current Issues and Research in Advertising, 22(2), 31-40. https://doi.org/10.1080/10641734.2000.1050 5106

Duke, C. R., \& Carlson, L. (1993). A conceptual approach to alternative memory measures for advertising effectiveness. Journal of Current Issues and Research in Advertising, 15(2), 1-14. https://doi.org/10.1080/10641734.1993.1050 5000

Engel, J.F. et.al., 1994, Consumer Behavior, Jilid 1, Alih Bahasa Budiyanto, Penerbit : Binarupa Aksara, Jakarta.Penerbit : Erlangga, Jakarta.

Folkvord, F. (2012). The effect of playing advergames promoting healthy or unhealthy foods on actual food intake among children. Appetite, $\quad$ 59(2), 625. https://doi.org/10.1016/j.appet.2012.05.062

Ghozali, I., 2016, Aplikasi Analisis Multivariate dengan Program SPSS. Semarang: Badan Penerbit Universitas Diponegoro

Ghirvu, A. (2013). in-Game Advertising: Advantages and Limitations for Advertisers. The USV Annals of Economics and Public Administration, 12(1), 114-119. Retrieved from http://seap.usv.ro/annals/ojs/index.php/anna Is/article/view/462\%5Cnhttp://seap.usv.ro/an nals/ojs/index.php/annals/article/viewArticle/ 462

Gould, S. J., \& Gupta, P. B. (2006). "COME ON DOWN": How Consumers View Game Shows and the Products Placed in Them. Journal of Advertising, 35(1), 65-81. https://doi.org/10.2753/JOA00913367350105

Grigorovici, D. M., \& Constantin, C. D. (2004). Experiencing Interactive Advertising beyond Rich Media. Journal of Interactive Advertising, 5(1), 22-36. https://doi.org/10.1080/15252019.2004.1072 2091

Gupta, P. B., \& Lord, K. R. (1998). Product placement in movies: The effect of prominence and mode on audience recall. Journal of Current Issues and Research in Advertising, 20(1), 47-59. 
https://doi.org/10.1080/10641734.1998.1050 5076

Herrewijn, L., \& Poels, K. (2017). Article information: https://doi.org/10.1108/JBIM-06-2016-0127

Karrh, J. A. (1998). Brand placement: A review. Journal of Currencartiert Issues and Research in Advertising, 20(2), 31-49. https://doi.org/10.1080/10641734.1998.1050 5081

Kotler, Philip dan Keller Kevin L., 2009. Manajeman Pemasaran. Edisi 13.Jakarta.Erlangga.

Kretchmer, S. B. (2011). Product placement effectiveness: revisited and renewed. Journal of Management \& Marketing Research, 6491(May), 1-24. https://doi.org/10.1300/J057v10n01

Kristanto, H., \& Karina M.R. Brahmana, R. (2016). Pengaruh Product Placement Pada Film Indonesia Terhadap Brand Awareness Dan Purchase Intention Masyarakat Surabaya. Jurnal Manajemen Pemasaran, 10(1), 2026.

https://doi.org/10.9744/pemasaran.10.1.2026

Kureshi, S., \& Sood, V. (2009). Indian gamers' recall, recognition and perceptions of in-game placements. Journal of Indian Business Research, 1(4), 252-268. https://doi.org/10.1108/17554190911013283

Kureshi, S., \& Sood, V. (2011). In-film placement trends: a comparative study of Bollywood and Hollywood. Journal of Indian Business Research, 3(4), 244-262. https://doi.org/10.1108/17554191111180591

Law, S., \& Braun, K. A. (2000). I'll have what she's having: Gauging the impact of product placements on viewers. Psychology and Marketing, 17(12), 1059-1075 https://doi.org/10.1002/(SICI)1520-

6793(200001)17:1<27::AIDMAR3>3.0.CO;2-C

Lee, M., \& Faber, R. J. (2007). Effects of Product Placement in On-Line Games on Brand Memory: A Perspective of the LimitedCapacity Model of Attention. Journal of Advertising, 36(4), 75-90. https://doi.org/10.2753/JOA00913367360406

Lessiter, J., Freeman, J., Keogh, E., \& Davidoff, J. (2001). A Cross-Media Presence Questionnaire: The ITC-Sense of Presence Inventory. Presence: Teleoperators and Virtual Environments, 10(3), 282-297. https://doi.org/10.1162/10547460130034361 2

Malhotra, Naresh K. 2009. Riset Pemasaran. Edisi keempat.Jakarta : Indeks
Mowen, J.C, Minor.M., 1998, Consumer Behavior. New York : Prentice Hall Inc

Nelson, M. R. (2002). Recall of brand placements in computer/video games. Journal of Advertising Research, 42(2), 80-92. https://doi.org/10.2501/JAR-42-2-80-92

Nicovich, S. G. (2005). The Effect of Involvement on Ad Judgment in a Video Game Environment. Journal of Interactive Advertising, 6(4), 29-39. https://doi.org/10.1080/15252019.2005.1072 2105

Nielsen, A. (n.d.). EPIC Dimensions of Advertising Effectiveness.

Panda, T. K. (2004). Effectiveness of Product Placements in Indian Films and its Effects on Brand Memory and Attitude with Special Reference to Hindi Films.

Petty, E. R., \& Cacioppo, T. J. (1986). The Elaboration Likelihood Model of Persuasion. Advances in Experimental Social Psychology, 19.

Quester, P., \& Lin Lim, A. (2003). Product involvement/brand loyalty: is there a link? Journal of Product \& Brand Management, 12(1), 22-38. https://doi.org/10.1108/10610420310463117

Schiffman, L.G. dan Kanuk, Lesley, L., 2010, Consumer Behavior, New Jersey: Perason Prestice Hall

Sumarwan, U., 2003, Perilaku Konsumen, Teori, dan Penerapannya dalam Pemasaran. Edisi Pertama. Indonesia: Ghalia

Tjiptono, Fandy. 2008. Strategi Pemasaran. ED. 3, Yogyakarta: Andi.

Van Reijmersdal, E. A., Rozendaal, E., \& Buijzen, M. (2012). Effects of Prominence, Involvement, and Persuasion Knowledge on Children's Cognitive and Affective Responses to Advergames. Journal of Interactive Marketing, 26(1), 33-42. https://doi.org/10.1016/j.intmar.2011.04.005

Vashisht, D., \& Pillai, S. S. (2011). Are you able to recall the brand? The impact of brand prominence, game involvement and persuasion knowledge in onlineadvergames. Journal of Product \& Brand Management. https://doi.org/10.1108/JHOM-09-2016-0165

Vashisht, D., \& Royne, M. B. (2016). Advergame speed influence and brand recall: The moderating effects of brand placement strength and gamers' persuasion knowledge. Computers in Human Behavior, 63, 162-169. https://doi.org/10.1016/j.chb.2016.05.022 
Waldt, V. der, Rey, D. la, Toit, L. Du, \& Redelinghuys, R. (2007). Does branded product placement in film enhance realism and product recognition by consumers? African Journal of Business Management, (May), 19-25. Retrieved from http://repository.up.ac.za/handle/2263/5164

Winkler, T., \& Buckner, K. (2006). Receptiveness of Gamers to Embedded Brand Messages in Advergames. Journal of Interactive Advertising, 7(1), 3-32. https://doi.org/10.1080/15252019.2006.1072 2123
Yang, M., Roskos-Ewoldsen, D. R., Dinu, L., \& Arpan, L. M. (2006). The Effectiveness of "in-Game" Advertising: Comparing College Students' Explicit and Implicit Memory for Brand Names. Journal of Advertising, 35(4), 143-152. https://doi.org/10.2753/JOA00913367350410

Yang, Y. T., Shu Hsun, H., \& Yu Ling, L. (2011). Ingame advertising: Consumers attitude and the effect of product placements on memory. African Journal of Business Management, 5(24), 10117-10127. https://doi.org/10.5897/AJBM11.377 